\title{
RECENT EXHIBITIONS
}

Several exhibits of the past half year have been closely connected with important events on the University calendar. During the month of November a large collection of autograph material of Walt Whitman was displayed in the exhibit area of the Lobby and the New Jersey Room. Most of the material was from the Charles E. Feinberg Collection, one of the finest gatherings of Whitman material in the world. The display included autograph letters and manuscripts, broadsides, and first editions of Whitman's works. On November I 3, Mr. Feinberg displayed the historic letter from Emerson greeting Whitman "at the beginning of a great career," and later in the evening lectured on Whitman's poetry.

Following an exhibition of autograph material of New Jersey authors, a second exhibit connected with a guest lecturer was displayed. Dr. David Mearns, Chief of the Manuscript Division of the Library of Congress, spoke on February 20 about the brief visit of Abraham Lincoln to New Jersey on February 21, I 86I, basing the lecture on material exhibited at the Library. In March the Library's extensive collection of American gift books was drawn upon for a display that covered every element of that unique form of publication. Copious examples were shown of such unusual features of gift books as their titles, ornate bindings, vignette title pages and presentation plates, their nationalism and regionalism, and the almost unbelievable extent of piracy by their publishers. Other parts of the exhibit dealt with the printing and engraving of gift books, their influence upon publishing, and their importance as a market for some of nineteenth century America's finest writers.

During the month of April Mr. and Mrs. Philip D. Sang and Mr. and Mrs. Morris Glasser lent to the Library for exhibit purposes a clay cylinder inscribed for Nebuchadnezzar II (604-56I B.c.). The cylinder is five and one-half inches long, three inches in diameter in the middle, and tapers to one and one-half inches in diameter at each end. It is inscribed with thirty-six lines of cuneiform writing, recording Nebuchadnezzar's building activities at Sippar. The inscription, which has been published in transliteration and translated by Langdon in Die Neubabylonischen Königsinschriften, states that the temple E-Barra was built at Sippar for "Shamash the Lord who lengthened my days." It then continues in a paean to Shamash interspersed with supplications to look graciously on the king's deeds, de- 
stroy his enemies, and solidify his throne. The last line is a particularly fine example of unintended irony, reminiscent of Shelley's "Ozymandias." In it, Nebuchadnezzar, the king who was struck with madness and "was driven from men and did eat grass as oxen and his body was wet with the dew of heaven," announces assuredly that "as the foundations of E-Barra are laid for eternity so may my years be lengthened forever."

The annual Rutgersensia display for Commencement was combined with two other displays, one of prints and manuscripts relating to Queen's building for its sesquicentennial in late April, and another display of autograph and pictorial material of past presidents of Rutgers, to honor the inauguration of President Gross on May 6. 